\title{
ANALISIS MISKONSEPSI MAHASISWA STKIP PGRI PACITAN PADA MATA KULIAH PENGANTAR DASAR MATEMATIKA POKOK BAHASAN LOGIKA DITINJAU DARI GAYA KOGNITIF MAHASISWA
}

\author{
Edi Irawan, Riyadi, Triyanto
}

\begin{abstract}
Abstrak
Miskonsepsi adalah gagasan yang tidak sesuai dengan pengertian ilmiah atau pengertian yang dicetuskan oleh para pakar dalam suatu bidang serta bisa berupa pengertian yang tidak akurat terhadap konsep, penggunaan konsep yang salah, klasifikasi contoh-contoh yang salah, kekacauan konsep-konsep yang berbeda dan hubungan hierarkis konsep-konsep yang tidak benar. Oleh karena itu, diperlukan informasi mengenai miskonsepsi untuk menghindari terjadinya miskonsepsi yang berkelanjutan. Salah satu faktor yang berpengaruh terhadap penguasaan konsep seseorang adalah gaya kognitif. Penelitian ini bertujuan untuk mengidentifikasi dan mendeskripsikan terjadinya miskonsepsi pada mata kuliah pengantar dasar matematika pokok bahasan logika, ditinjau dari gaya kognitif mahasiswa.

Penelitian ini termasuk penelitian deskriptif kualitatif dengan metode studi kasus. Subjek pada penelitian ini adalah mahasiswa semester satu Program Studi Pendidikan Matematika STKIP PGRI Pacitan, tahun 2011. Teknik yang digunakan dalam pengambilan subjek adalah purposive sampling. Identifikasi terjadinya miskonsepsi dilakukan dengan menggunakan teknik Certainly of Response Index(CRI) yang dikembangkan oleh Saleem Hasan. Sedangkan identifikasi gaya kognitif mahasiswa dilakukan dengan menggunakan instrumen Group Embedded Figures Test(GEFT) yang dikembangkan oleh Witkin. Analisis data hasil penelitian dilakukan dengan menggunakan model Miles dan Huberman.

Hasil penelitian menunjukkan bahwa proporsi miskonsepsi pada mahasiswa dengan gaya kognitif Field dependent $(F D)$ lebih tinggi dibandingkan dengan miskonsepsi pada mahasiswa dengan gaya kognitif Field independent(FI). Mahasiswa FD lebih banyak mengalami miskonsepsi pada konsep invers, konvers, dan kontraposisi (38\%) sedangkan pada mahasiswa FI lebih banyak mengalami miskonsepsi pada konsep negasi pernyataan majemuk dan pernyataan berkuantor (32\%). Miskonsepsi pada mahasiswa FD lebih banyak disebabkan oleh prakonsepsi yang salah dan rendahnya kemampuan mahasiswa. Sedangkan miskonsepsi pada mahasiswa FI lebih banyak disebabkan oleh Simplifikasi dan intuisi yang salah dari mahasiswa.
\end{abstract}

Kata kunci: $\quad$ miskonsepsi, gaya kognitif, $C R I$, GEFT.

\section{PENDAHULUAN}

\section{Latar Belakang Masalah}

$$
\text { Pengantar Dasar Matematika }
$$

merupakan salah satu mata kuliah yang diajarkan di Program Studi Pendidikan Matematika STKIP PGRI Pacitan. Mata kuliah ini diberikan pada semester I dengan bobot 3 SKS. Tujuan mata kuliah ini adalah agar mahasiswa memiliki keterampilan belajar matematika sehingga dapat menjelaskan dan menerapkan konsep-konsep penalaran dan konsep dasar logika yang merupakan landasan untuk mempelajari mata kuliah yang lain.
Mengingat mata kuliah ini merupakan landasan untuk mempelajari mata kuliah yang lain, maka akan sangat penting untuk dikuasai mahasiswa. Berdasarkan hasil pengamatan yang dilakukan peneliti, ternyata prestasi mahasiswa pada Mata kuliah Pengantar Dasar Matematika kurang memuaskan. Terbukti berdasarkan laporan Biro Administrasi Akademik STKIP PGRI Pacitan, dalam tiga tahun terakhir nilai Mata kuliah Pengantar Dasar Matematika mahasiswa matematika sebagian besar adalah B dan C. Data lebih lengkapnya adalah sebagaimana Tabel 1. 
Tabel 1. Nilai Pengantar Dasar Matematika Mahasiswa Program Studi Pendidikan Matematika STKIP PGRI Pacitan

\begin{tabular}{cccc}
\hline Nilai & $\mathbf{2 0 0 7 / 2 0 0 8}$ & $\mathbf{2 0 0 8 / 2 0 0 9}$ & $\mathbf{2 0 0 9 / 2 0 1 0}$ \\
\hline A & $1 \%$ & $18 \%$ & $8 \%$ \\
B & $53 \%$ & $37 \%$ & $30 \%$ \\
C & $46 \%$ & $37 \%$ & $48 \%$ \\
D & $0 \%$ & $9 \%$ & $11 \%$ \\
E & $0 \%$ & $0 \%$ & $3 \%$ \\
\hline
\end{tabular}

Terjadinya penurunan prestasi mata

kuliah pengantar dasar matematika tersebut, disebabkan oleh menurunnya prestasi mahasiswa pada pokok bahasan logika. Berdasarkan hasil wawancara awal dengan dosen pengampu, diketahui bahwa penyebab menurunnya prestasi pada pokok bahasan logika disebabkan oleh terjadinya ketidaktahuan konsep dan miskonsepsi. Miskonsepsi menjadi faktor tertinggi yang menyebabkan menurunnya prestasi mahasiswa.

Adanya miskonsepsi pada mahasiswa dapat menyebabkan adanya kesulitan mahasiswa dalam memahami konsep-konsep matematika selanjutnya (Dahar 1996). Mahasiswa tidak mungkin dapat menguasai konsep-konsep matematika lebih lanjut, apabila struktur kognitifnya tersusun dari miskonsepsimiskonsepsi. Lebih lagi menurut Hewson (Sunarno 1988) beberapa hasil penelitian menunjukkan bahwa miskonsepsi dapat bertahan atau resisten. Apabila dosen tidak memperhatikan konsep yang telah dimiliki mahasiswa, maka sangat memungkinkan miskonsepsi menjadi lebih kompleks dan stabil. Bila permasalahan ini tidak segera diatasi, maka pemahaman mahasiswa terhadap topik-topik yang lebih tinggi akan terhambat. Dalam jangka waktu yang relatif lama akan terjadi akumulasi ketidakmampuan mahasiswa dalam menguasai
Miskonsepsi dapat dipandang sebagai suatu konsepsi atau struktur kognitif yang melekat dengan kuat dan stabil di benak mahasiswa yang sebenarnya menyimpang dari konsepsi yang dikemukakan oleh para ahli. Sehingga miskonsepsi sangat erat kaitannya dengan gaya kognitif yang dimiliki seseorang. Gaya kognitif adalah karakteristik individu dalam penggunaan fungsi kognitif (berpikir, mengingat, memecahkan masalah, membuat keputusan, mengorganisasi dan memproses informasi, dan seterusnya) yang bersifat konsisten dan berlangsung lama (Desmita 2006). Gaya kognitif menempati posisi yang penting dalam proses pembelajaran.

Menyikapi permasalahan yang timbul pada pembelajaran Mata Kuliah Pengantar Dasar Matematika tersebut, maka perlu dilakukan penelitian guna menganalisis permasalahan ini, agar dapat diatasi dan ditanggulangi. Langkah awal yang harus dilakukan adalah mengidentifikasi terjadinya miskonsepsi terlebih dahulu. Usaha untuk mengidentifikasi miskonsepsi sebenarnya telah banyak dilakukan. Namun hingga saat ini masih terdapat kesulitan dalam membedakan antara mahasiswa yang mengalami miskonsepsi dengan yang tidak tahu konsep. Kesalahan pengidentifikasian miskonsepsi akan 
menyebabkan kesalahan dalam penanggulangannya, sebab penanggulangan mahasiswa yang mengalami miskonsepsi akan berbeda penanggulangannya dengan mahasiswa yang tidak tahu konsep. Sebagai salah satu alternatif yang digunakan untuk mengidentifikasi miskonsepsi adalah teknik Certainly of Response Index(CRI) yang dikembangkan oleh Saleem Hasan.

\section{Rumusan Masalah}

Permasalahan yang menjadi fokus penelitian ini adalah sebagai berikut:

1. Miskonsepsi-miskonsepsi apakah yang terjadi pada mahasiswa Field dependen $(F D)$, khususnya pada pokok bahasan logika;

2. Miskonsepsi-miskonsepsi apakah yang terjadi pada mahasiswa Field independen (FI), khususnya pada pokok bahasan logika;

3. Apakah penyebab terjadinya miskonsepsi pada mahasiswa Field dependen (FD), khususnya pada pokok bahasan logika;

4. Apakah penyebab terjadinya miskonsepsi pada mahasiswa Field independen (FI), khususnya pada pokok bahasan logika.

\section{Tujuan Penelitian}

Berdasarkan rumusan masalah di atas, maka tujuan penelitian ini adalah untuk mendeskripsikan dan menganalisis miskonsepsi mahasiswa Program Studi Pendidikan Matematika STKIP PGRI Pacitan, pada pokok bahasan logika, ditinjau dari gaya kognitif yang dimilikinya. Adapun sub tujuan dari penelitian ini adalah:

1. Untuk mengidentifikasi terjadinya miskonsepsi pada mahasiswa yang memiliki gaya kognitif Field dependen $(F D)$;

2. Untuk mengidentifikasi terjadinya miskonsepsi pada mahasiswa yang memiliki gaya kognitif Field independent $(F I)$;

3. Untuk mendeskripsikan penyebab terjadinya miskonsepsi pada mahasiswa yang memiliki gaya kognitif Field dependen $(F D)$;

4. Untuk mendeskripsikan apa penyebab terjadinya miskonsepsi pada mahasiswa yang memiliki gaya kognitif Field independent (FI).

\section{Manfaat Penelitian}

Hasil penelitian ini diharapkan dapat memberi manfaat baik bagi mahasiswa, dosen, atau pihak lain yang berkepentingan. Adapun manfaat tersebut adalah sebagai berikut:

1. Secara teoritis

Secara umum penelitian ini diharapkan dapat menambah dan mengembangkan ilmu pengetahuan mengenai miskonsepsi serta dapat menambah dan mengembangkan pengetahuan mengenai gaya kognitif.

2. Secara Praktis

Dengan adanya penelitian ini diharapkan dapat memberikan masukan khususnya kepada dosen agar dapat merancang pembelajaran yang mampu membantu mahasiswa dalam menanggulangi terjadinya miskonsepsi yang dilihat dari gaya kognitif mahasiswa. 


\section{KAJIAN TEORI}

\section{Miskonsepsi}

Miskonsepsi merupakan pertentangan atau ketidakcocokan konsep yang dipahami seseorang dengan konsep yang dipakai oleh para pakar ilmu yang bersangkutan (Den Berg 1991). Sedangkan menurut Brown (Dahar 1996) miskonsepsi didefinisikan sebagai suatu pandangan yang naif, suatu gagasan yang tidak cocok dengan pengertian ilmiah yang sekarang diterima. Pendapat lain tentang miskonsepsi di kemukakan Fowler (Suparno 2005), bahwa miskonsepsi memiliki arti sebagai sesuatu yang tidak akurat akan konsep, penggunaan konsep yang salah, klasifikasi contoh yang salah, kekacauan konsep-konsep yang berbeda dan hubungan hierarki konsep-konsep yang tidak benar. Sedangkan menurut Suhadi (1989) batasan miskonsepsi adalah apabila pemahaman mahasiswa terhadap suatu konsep berbeda dengan apa yang dipahami atau dimaksudkan masyarakat ilmiah ataupun kurikulum termasuk di dalamnya buku-buku acuan yang dipakai.

Dari beberapa pendapat di atas, dapat disimpulkan bahwa yang dimaksud miskonsepsi pada penelitian ini adalah gagasan yang tidak sesuai dengan pengertian ilmiah atau pengertian yang dicetuskan oleh para pakar dalam suatu bidang serta bisa berupa pengertian yang tidak akurat terhadap konsep, penggunaan konsep yang salah, klasifikasi contoh-contoh yang salah, kekacauan konsep-konsep yang berbeda dan hubungan hierarkis konsep-konsep yang tidak benar.

\section{Identifikasi Miskonsepsi}

Usaha untuk mengidentifikasi miskonsepsi telah banyak dilakukan, namun hingga saat ini masih terdapat kesulitan dalam membedakan antara mahasiswa yang mengalami miskonsepsi dengan yang tidak tahu konsep (Liliawati 2008). Kesalahan pengidentifikasian miskonsepsi akan menyebabkan kesalahan dalam penanggulangannya, sebab penanggulangan mahasiswa yang mengalami miskonsepsi akan berbeda penanggulangannya dengan mahasiswa yang tidak tahu konsep. Sebagai salah satu alternatif yang digunakan untuk mengidentifikasi miskonsepsi adalah teknik Certainly of Response Index(CRI) yang dikembangkan oleh Saleem Hasan.

CRI sering kali digunakan dalam survei-survei, terutama yang meminta responden untuk memberikan derajat kepastian yang dia miliki dari kemampuannya untuk memilih dan mengorganisasi pengetahuan, konsep-konsep, atau hukum-hukum yang terbentuk dengan baik dalam dirinya untuk menentukan jawaban dari suatu pertanyaan (soal). CRI biasanya didasarkan pada suatu skala, sebagai contoh, skala enam (0 - 5) seperti pada Tabel 2 (Hasan et al. 1999).

Tabel 2. CRI dan kriterianya

\begin{tabular}{cll}
\hline CRI & \multicolumn{1}{c}{ Kriteria } & \multicolumn{1}{c}{ Keterangan } \\
\hline 0 & $\begin{array}{l}\text { Totally guessed answer (menebak } \\
\text { seluruhnya) }\end{array}$ & 100\% jawaban ditebak \\
1 & Almost guess (hampir menebak) & Unsur tebakan antara 75-99\% \\
2 & Not Sure (ragu) & Unsur tebakan antara 50-74\% \\
3 & Sure (yakin atau benar) & Unsur tebakan antara 25-49\%
\end{tabular}




\begin{tabular}{cll}
\hline $\boldsymbol{C R I}$ & \multicolumn{1}{c}{ Kriteria } & \multicolumn{1}{c}{ Keterangan } \\
\hline 4 & Almost certain (hampir pasti) & Unsur tebakan antara 1-24\% \\
5 & Certain (pasti) & Tidak ada unsur tebakan sama sekali \\
& & $(0 \%)$ \\
\hline
\end{tabular}

Tabel 3 di bawah menunjukkan empat kemungkinan kombinasi dari jawaban (benar atau salah) dan $C R I$ (tinggi atau rendah) untuk tiap responden secara individu. Untuk seorang responden dan untuk suatu pertanyaan yang diberikan, jawaban benar dengan CRI rendah menandakan tidak tahu konsep, dan jawaban benar dengan CRI tinggi menunjukkan penguasaan konsep yang tinggi. Jawaban salah dengan $C R I$ rendah menandakan tidak tahu konsep, sementara jawaban salah dengan $C R I$ tinggi menandakan terjadinya miskonsepsi.

Tabel 3. Ketentuan untuk membedakan antara tahu konsep, miskonsepsi dan tidak tahu konsep untuk responden secara individu

\begin{tabular}{cll}
\hline $\begin{array}{c}\text { Kriteria } \\
\text { jawaban }\end{array}$ & \multicolumn{1}{c}{ CRI rendah $(<\mathbf{2 , 5})$} & \multicolumn{1}{c}{ CRI tinggi $(>\mathbf{2 , 5 )}$} \\
\hline Jawaban benar & $\begin{array}{l}\text { Jawaban benar tapi } C R I \text { rendah } \\
\text { berarti tidak tahukonsep } \\
\text { (lucky guess) }\end{array}$ & $\begin{array}{l}\text { Jawaban benar dan } C R I \text { tinggi } \\
\text { berarti menguasai konsep } \\
\text { dengan baik }\end{array}$ \\
Jawaban salah & $\begin{array}{l}\text { Jawaban salah dan } C R I \text { rendah } \\
\text { berarti tidak tahu konsep }\end{array}$ & $\begin{array}{l}\text { Jawaban salah tapi } C R I \text { tinggi } \\
\text { berarti terjadi miskonsepsi }\end{array}$ \\
\hline
\end{tabular}

(Sumber: Hasan et al. 1999)

\section{Penyebab Terjadinya Miskonsepsi}

Penyebab terjadinya miskonsepsi adalah siswa, guru, buku teks, konteks, dan metode mengajar (Suparno 2005). Miskonsepsi yang terjadi pada diri siswa dapat berasal dari prakonsepsi, pemikiran asosiatif, pemikiran humanistis, reasoning yang tidak lengkap, intuisi yang salah, tahap perkembangan kognitif siswa, kemampuan siswa, dan minat belajar siswa.

\section{Gaya Kognitif (Cognitive Style)}

Gaya kognitif merupakan salah satu ide baru dalam kajian psikologi perkembangan dan pendidikan. Ide ini berkembang pada penelitian bagaimana individu menerima dan mengorganisasi informasi dari lingkungan sekitarnya. Hasil kajian ini menunjukkan bahwa individu berbeda-beda dalam hal bagaimana mereka mendekati tugas eksperimental, tetapi variasi ini tidak merefleksikan tingkat intelegensi atau pola kemampuan khusus. Bahkan mereka melakukannya dengan cara yang dipilih yang dimiliki individu berbeda untuk memproses dan mengorganisasi informasi dan untuk merespons stimulan lingkungan (Woolfolk \& Nicolich cit. Desmita 2009).

Messick dalam Guisande (2007), secara sederhana mendefinisikan gaya kognitif sebagai "characteristic ways in which individuals perceive environmental stimuli, and organize and cue information". Sejalan dengan itu, Hayes \& Allinson (1998) menyatakan bahwa: "A cognitive style influences how people look at their environment for information, how they organize and interpret this information, and how they use these interpretations to guide their Action."

Berdasarkan pada beberapa definisi di 
atas, dapat dipahami bahwa yang dimaksud dengan gaya kognitif adalah karakteristik individu dalam penggunaan fungsi kognitif (berpikir, mengingat, memecahkan masalah, membuat keputusan, mengorganisasi dan memproses informasi, dan seterusnya) yang bersifat konsisten dan berlangsung lama.

\section{Tipe Gaya Kognitif}

Para ahli psikologi dan pendidikan berbeda pendapat dalam mengemukakan bentuk-bentuk gaya kognitif yang digunakan oleh peserta didik. Gaya kognitif yang akan dibicarakan pada penelitian ini adalah Field
dependent-Field independent (FD-FI). Alasan pemilihan gaya kognitif ini dikarenakan gaya kognitif $F D$ dan FI merupakan tipe yang paling tepat, untuk digunakan dalam melihat dan menganalisis terjadinya miskonsepsi pada mahasiswa. Di samping itu, pengelompokan kedua gaya kognitif ini mudah. Sebagaimana saran Witkin (Eunjoo Oh 2005), gaya Field dependent-Field independent (FD-FI) pada penelitian ini di bedakan lagi dalam tiga kelompok, yakni Field dependent(FD), Field neutral(FN), atau Field independent (FI).

Tabel 4. Perbandingan karakter seseorang dengan gaya kognitif Field dependent(FD) dan Field independent(FI) Menurut Witkin

\begin{tabular}{ll}
\hline \multicolumn{1}{c}{ Field dependent $(\boldsymbol{F D})$} & \multicolumn{1}{c}{ Field independent $(\boldsymbol{F I})$} \\
\hline $\begin{array}{l}\text { Berusaha keras untuk menyusun kembali } \\
\text { informasi dan menempa hubungan dengan }\end{array}$ & $\begin{array}{l}\text { Mampu mengorganisasi kembali suatu } \\
\text { penteks pengetahuan awal/sebelumnya }\end{array}$ \\
Kepribadian menunjukelumna & \\
arah sosial & Sedikit dipengaruhi oleh intensifikasi \\
Dalam membuktikan sesuatu cenderung & sosial \\
kurang menggunakan keterampilan & lebiam membuktikan sesuatu cenderung \\
penalaran & penalaran \\
Lebih suka belajar dalam kelompok & Lebih suka belajar sendiri \\
Dipengaruhi oleh figur tokoh & Bekerja secara individual \\
Diarahkan secara eksternal & Diarahkan secara internal \\
Menerima ide-ide secara langsung & Menerima penguatan ide-ide melalui \\
& analisis \\
\hline
\end{tabular}

Seorang mahasiswa dengan gaya informasi. Mereka mengerjakan tugas secara kognitif $F D$ menemukan kesulitan dalam memproses, namun mudah memersepsi apabila informasi dimanipulasi sesuai dengan konteksnya. Ia akan dapat memisahkan stimulan dalam konteksnya, tetapi persepsinya lemah ketika terjadi perubahan konteks. Sementara itu, mahasiswa dengan gaya kognitif FI cenderung menggunakan faktor-faktor internal sebagai arahan dalam memproses tidak berurutan dan merasa efisien bekerja sendiri. Hal ini sejalan dengan penelitian yang dilakukan oleh Atasoy et al. (2008) yang menunjukkan bahwa mahasiswa dengan gaya kognitif $F D$ lebih suka menyelesaikan sesuatu dengan cara yang telah ditetapkan sementara mahasiswa dengan gaya kognitif FI cenderung lebih menyukai penyelesaian yang tidak linier.

Pengukuran Gaya Kognitif $F D-F I$ 
Instrumen tes yang digunakan untuk memisahkan gaya kognitif mahasiswa pada penelitian ini adalah Embedded Figures Test(EFT). Dikarenakan subjek yang akan diteliti pada penelitian ini adalah mahasiswa yang usianya di atas 10 tahun, maka lebih spesifik lagi digunakan Group Embedded Figures Test(GEFT). Alasan pemilihan tes ini adalah karena GEFT merupakan tes yang hanya menggunakan kertas dan pensil (pencil and paper test) sebagai alat yang digunakan sehingga mempermudah peneliti dalam melakukan tes tersebut. Selain itu, GEFT merupakan tes standar yang memiliki skala tetap dengan skor 0 sampai 18 di mana setiap jawaban benar bernilai 1 dan jawaban salah bernilai 0 , sehingga penilaian yang dilakukan bersifat lebih objektif. Tes yang digunakan ini terdiri dari 25 gambar kompleks yang terbagi ke dalam 3 tahap. Tahap pertama terdiri dari 7 gambar sedangkan tahap kedua dan ketiga masing-masing terdiri dari 9 gambar. Terdapat 8 gambar sederhana yang dinamai A, B, C, D, E, F, G dan $\mathrm{H}$ yang harus ditemukan pada ke-25 gambar pada soal dengan cara memberi garis tebal pada gambar tersebut.

\section{Kerangka Pikir}

Pengetahuan yang berkembang pada diri peserta didik tidak hanya diperoleh ketika mereka diajarkan suatu konsep oleh seorang dosen atau membaca buku, tetapi sebagai manusia mereka senantiasa aktif membangun struktur kognitifnya berdasarkan pemilihan informasi yang tersedia sesuai dengan keinginannya. Berdasarkan hal ini, maka sering kali miskonsepsi terjadi. Ketika mereka berusaha membangun struktur kognitif dengan memilih informasi yang ada, kemungkinan ada kesalahan dalam mengaitkan keduanya. Prakonsepsi dan konsepsi yang benar dapat menjadi salah ketika ia membangun struktur kognitif baru berdasarkan masukan informasi yang salah, atau sebaliknya. Semuanya itu menyebabkan terjadinya miskonsepsi pada diri peserta didik.

Materi logika matematika tidak mengandung perhitungan, tetapi mengandung banyak konsep yang perlu kemampuan yang lebih dari sekedar dihafal. Oleh karena itu untuk menguasai materi ini dengan baik dan benar sangat diperlukan kemampuan peserta didik untuk mendalami hubungan antar konsep agar mampu membangun struktur kognitif yang benar tentang materi logika matematika. Namun demikian, karena isi materi ini sangat kompleks dan abstrak, kemungkinan terjadi miskonsepsi peserta didik pada materi logika matematika relatif besar.Hal ini bisa disebabkan oleh diri mahasiswa sendiri, dosen pengampu atau buku teks yang digunakan.

Miskonsepsi merupakan suatu keadaan yang dapat dialami oleh setiap peserta didik, namun bukan berarti dibiarkan begitu saja terjadi. Banyak instrumen pendeteksi miskonsepsi telah dikembangkan, mulai dari yang berbentuk (1) peta konsep; (2) tes pilihan ganda dan tes esai tertulis; (3) wawancara diagnostik; (4) diskusi kelas; sampai yang berupa (5) praktikum dengan tanya jawab. Semua instrumen memiliki kelebihan di samping kekurangan. Pada penelitian ini dideteksi melalui sebuah tes uraian yang disertai dengan Certainly of Response Index (CRI) sebagaimana yang dikembangkan oleh 
Saleem Hasan.

Pemahaman seorang peserta didik termasuk halnya mahasiswa juga dipengaruhi oleh berbagai faktor, baik internal maupun eksternal. Penguasaan konsep yang salah, dapat menyebabkan miskonsepsi. Miskonsepsi sangat dipengaruhi oleh bagaimana seseorang memanfaatkan struktur kognitifnya. Struktur kognitif, erat kaitannya dengan gaya kognitif seseorang. Salah satu pengelompokkan gaya kognitif adalah gaya kognitif Field dependent (FD) dan Field independent (FI).Kedua gaya ini dibedakan menurut sejauh mana seseorang terpengaruh latar belakang pendidikan sebelumnya dan lingkungan sekitarnya. Masing-masing gaya kognitif tersebut, memiliki karakteristik miskonsepsi sendiri-sendiri.

\section{METODOLOGI PENELITIAN}

\section{Tempat dan Waktu}

Penelitian ini dilaksanakan di STKIP PGRI Pacitan, yang beralamatkan di Jalan Cut Nyak Dien No. 4A Ploso, Kabupaten Pacitan, Provinsi Jawa Timur. Penelitian ini dilaksanakan selama sembilan bulan, mulai bulan Juli 2011 sampai bulan Maret 2012 .

\section{Jenis Penelitian}

Penelitian ini termasuk penelitian deskriptif kualitatif dengan metode studi kasus. Penelitian kualitatif adalah penelitian yang bermaksud untuk memahami fenomena tentang apa yang dialami oleh subjek penelitian secara holistik, dan dengan cara deskripsi dalam bentuk kata-kata dan bahasa, pada suatu konteks khusus yang alamiah dan dengan memanfaatkan berbagai metode alamiah (Moloeng 2006). Penelitian deskriptif merupakan suatu penelitian yang ditujukan untuk mendeskripsikan suatu keadaan atau fenomena-fenomena apa adanya (Sukmadinata 2010). Sedangkan metode penelitian studi kasus adalah suatu penelitian yang dilakukan terhadap suatu "kesatuan sistem" (Sukmadinata 2010). Pada penelitian ini, kasus yang akan diteliti dan dideskripsikan merupakan situasi khusus, yaitu miskonsepsi pokok bahasan logika pada mahasiswa program studi pendidikan matematika.

\section{Subjek Penelitian}

Subjek dalam penelitian ini adalah mahasiswa Program Studi Pendidikan Matematika pada semester satu tahun akademik 2011/2012 yang terdiri dari dua kelas, yakni kelas A dan B.

\section{Teknik Sampling}

Teknik pengambilan subjek pada penelitian ini adalah purposive sampling. Purposive sampling adalah teknik penentuan sampel dengan pertimbangan tertentu (Sugiyono 2011). Pertimbangan pengambilan subjeknya adalah berdasarkan hasil tes gaya kognitif mahasiswa dan juga tes diagnostik miskonsepsi mahasiswa.

\section{Teknik Pengumpulan Data}

Sesuai dengan bentuk pendekatan penelitian kualitatif dan sumber data yang akan digunakan, maka teknik pengumpulan data yang digunakan menggunakan metode dokumentasi, metode tes, dan wawancara.

\section{Instrumen Penelitian}

Sebagaimana umumnya penelitian, 
teknik pengumpulan data pada penelitian ini menggunakan instrumen penelitian. Bogdan dan Biklen (Sugiyono 2011) menyatakan bahwa salah satu ciri penelitian kualitatif adalah dilakukan pada kondisi alamiah, (sebagai lawannya adalah eksperimen), langsung ke sumber data dan peneliti adalah instrumen kunci. Senada dengan itu, Wahidmuri (2008) menyatakan bahwa pada penelitian kualitatif, instrumen utama atau kuncinya adalah peneliti itu sendiri. Namun demikian, dalam pengumpulan data ia tetap menggunakan instrumen penelitian lain seperti pedoman wawancara, pedoman pengamatan, pedoman dokumentasi atau bahkan kuesioner. Adapun instrumen pada penelitian ini adalah peneliti sebagai instrumen utama dibantu dengan instrumen bantu I yakni tes GEFT, instrumen bantu II berupa tes diagnostik miskonsepsi dan instrumen bantu III berupa pedoman wawancara.

Instrumen GEFT merupakan tes yang non verbal dan sifat dari psikometrik tes telah diuji dalam lintas budaya (Altun dan Cakan 2006). Berdasarkan rumus Spearman-Brown di laporan bahwa reliabilitas tes $G E F T$ adalah 0,82 untuk siswa laki-laki $(\mathrm{N}=80)$ dan siswa perempuan $(\mathrm{N}=97)$. Fyle (2009) menyatakan bahwa validitas, reliabilitas, dan konsistensi internal pada GEFTtersebut,didukung oleh laporan beberapa hasil penelitian, diantaranya yang dilakukan oleh Panek, Funk, dan Nelson pada tahun 1980, Cumming dan Murray pada tahun 1987,dan Day, McRae, serta Young pada tahun 1990.

\section{The Group Embedded Figures} Test(GEFT) ini terdiri dari 3 bagian dengan total waktu pengerjaan selama 15 menit. Tahap pertama terdiri dari 7 buah soal, tahap kedua dan ketiga masing-masing terdiri dari 9 soal. Setiap nomor diberi skor 1 untuk mahasiswa yang menjawab benar dan skor 0 untuk mahasiswa yang menjawab salah. Skor yang dihitung adalah hanya bagian kedua dan ketiga saja, bagian pertama dimaksudkan sebagai latihan. Skor tes ini dari 0 sampai dengan 18. Mahasiswa yang lebih banyak menjawab dengan benar cenderung tergolong pada mahasiswa dengan gaya kognitif $F I$.

Interpretasi skor GEFT pada penelitian ini didasarkan pada aturan Dyer dan Osborne (1996) sebagai berikut.

\begin{tabular}{|c|c|c|}
\hline Abstrak & & Konkret \\
\hline Field Dependent & Field Neutral & Field Independent \\
\hline
\end{tabular}

0

89

1011

18

Gambar 3. Interpretasi Skor GEFT

\section{Validitas Data}

Sebagaimana penelitian kualitatif lainnya, validitas data hasil penelitian ini menggunakan triangulasi. Menurut Moloeng (2006), triangulasi adalah teknik pemeriksaan keabsahan data yang memanfaatkan sesuatu yang lain di luar data untuk keperluan pengecekan atau sebagai pembanding terhadap data itu. Pengujian keabsahan data pada penelitian ini menggunakan triangulasi teknik. Triangulasi teknik adalah penggunaan beragam teknik pengungkapan data yang dilakukan 
kepada sumber data (Satori 2010). Hal ini dilakukan dengan cara mengecek data kepada sumber yang sama dengan teknik yang berbeda (Sugiyono 2011). Pada penelitian ini, triangulasi dilakukan dengan membandingkan hasil tes diagnostik miskonsepsi dengan hasil wawancara mendalam.

\section{Teknik Analisis Data}

Teknik analisis data yang digunakan adalah deskriptif naratif dengan menggunakan model Miles dan Huberman. Miles dan Huberman (Sugiyono 2011), yang mengemukakan bahwa aktivitas dalam analisis data kualitatif dilakukan secara interaktif dan berlangsung secara terus-menerus sampai tuntas, sehingga datanya jenuh. Ukuran kejenuhan data ditandai dengan tidak diperolehnya lagi data atau informasi baru. Aktivitas dalam analisis meliputi reduksi data (data reduction), penyajian data (data display), serta penarikan kesimpulan dan verifikasi (conclusion drawing/verification).

\section{HASIL PENELITIAN}

\section{Hasil Penentuan Gaya Kognitif}

Hasil penelitian gaya kognitif mahasiswa Program Studi Pendidikan Matematika STKIP PGRI Pacitan tahun akademik 2011/2012, dengan menggunakan instrumen penggolongan gaya kognitif yang dikembangkan oleh Witkin yakni Group Embedded FIgures Test (GEFT) adalah sebagaimana tabel berikut.

Tabel 1. Gaya Kognitif Mahasiswa Program Studi Pendidikan Matematika Semester I Tahun Angkatan 2010/2011

\begin{tabular}{lcccc}
\hline \multirow{2}{*}{ Gaya Kognitif } & \multicolumn{3}{c}{ Jumlah } & \multirow{2}{*}{ Persentase } \\
\cline { 2 - 4 } & Kelas A & Kelas B & Total & \\
\hline Field dependent $(F D)$ & 20 & 25 & 45 & $49 \%$ \\
Field neutral $(F N)$ & 9 & 9 & 18 & $20 \%$ \\
Field independent $(F I)$ & 15 & 13 & 28 & $31 \%$ \\
Total & 44 & 47 & 91 & $100 \%$ \\
\hline
\end{tabular}

\section{Hasil Tes Diagnostik Miskonsepsi}

Tes diagnostik miskonsepsi yang diberikan berupa tes uraian pada pokok bahasan logika, yang disertai dengan Certanty of Response Index (CRI). Tes ini digunakan untuk mengetahui apakah seorang mahasiswa tahu konsep, tidak tahu konsep, atau mengalami miskonsepsi, pada masing-masing konsep yang ada pada pokok bahasan logika. Prosedur penentuan apakah seorang mahasiswa tahu konsep, tidak tahu konsep, atau mengalami miskonsepsi,didasarkan pada jawaban soal dan nilai CRI yang diberikan, dengan kriteria penentuan sebagaimana tercantum pada Tabel 3.

Setelah dilakukan tes diagnostik dan reduksi terhadap hasil pekerjaan mahasiswa, diperoleh data miskonsepsi pada tiap butir soal berdasarkan gaya kognitifnya sebagai berikut. 


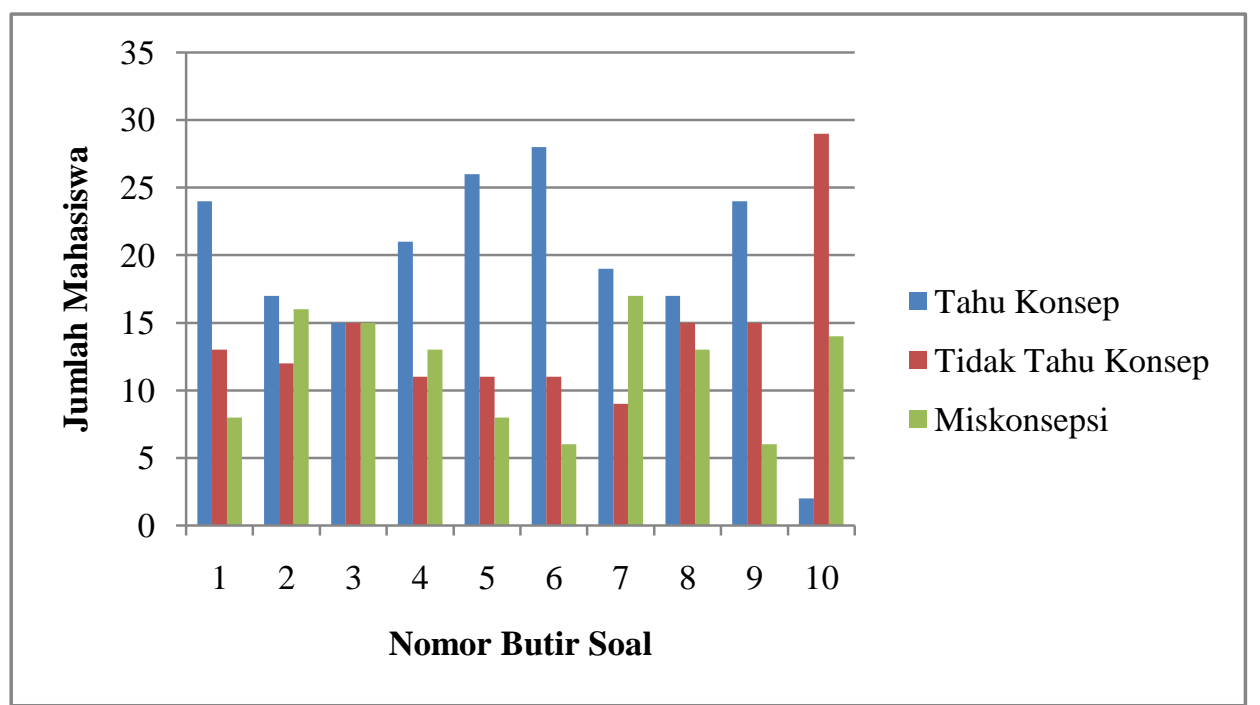

Gambar 1. Sebaran mahasiswa Field Dependent(FD) menurut penguasaan konsep yang dimilikinya

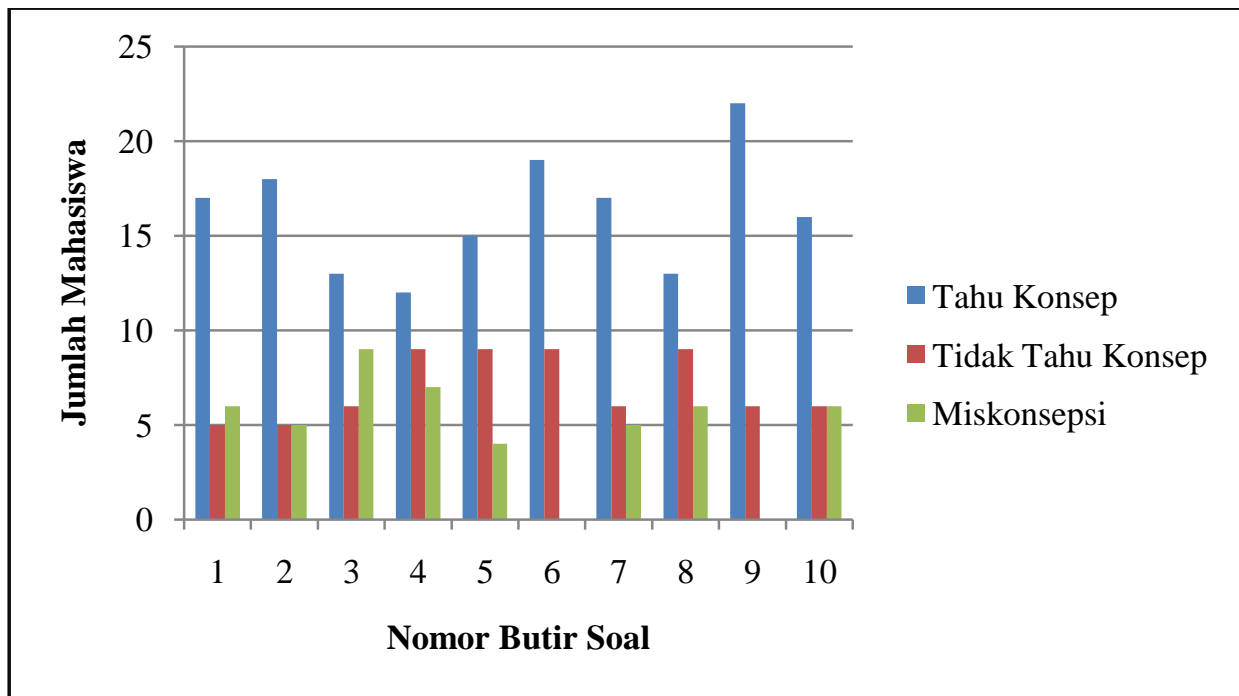

Gambar 2. Sebaran mahasiswa Field Independent (FI) menurut penguasaan konsep yang dimilikinya.

\section{Pembahasan}

Berdasarkan paparan data dan analisis yang telah dilakukan sebelumnya, terlihat terjadinya miskonsepsi mahasiswa pada materi logika, baik pada mahasiswa yang memiliki gaya kognitif Field dependent maupun yang memiliki gaya kognitif Field independent. Miskonsepsi pada mahasiswa dengan gaya kognitif Field dependent secara kuantitas dan juga proporsi lebih tinggi dibandingkan dengan mahasiswa dengan gaya kognitif Field independent. Berikut akan dibahas bagaimana terjadinya miskonsepsi mahasiswa pada materi logika sesuai dengan gaya kognitifnya masingmasing.

\section{Miskonsepsi mahasiswa Field dependent}

Miskonsepsi pada mahasiswa gaya kognitif Field dependent terjadi pada semua konsep pada logika matematika. Dari sepuluh soal yang ada, dengan berbagai konsep masingmasing, menunjukkan bahwa tiap butir soal terdapat mahasiswa yang mengalami miskonsepsi. Berbagai miskonsepsi pada 
mahasiswa $F D$ pada mata kuliah pengantar dasar matematika pokok bahasan logika adalah sebagai berikut.

a. Miskonsepsi pada konsep pernyataan atau bukan pernyataan

Pada konsep ini mahasiswa $F D$ mengalami miskonsepsi dalam memberikan definisi kalimat terbuka. Definisi yang diberikan tidak sesuai dengan konsep logika. Demikian halnya dalam memberikan contoh. Beberapa mahasiswa $F D$ benar dalam memberikan definisi, namun demikian salah dalam memberikan contoh. Hal ini menunjukkan mahasiswa mengalami miskonsepsi dalam hal contohcontoh suatu konsep.

b. Miskonsepsi pada konsep pernyataan majemuk dan pernyataan berkuantor beserta negasinya

Pada konsep ini mahasiswa $F D$ mengalami miskonsepsi dalam menentukan negasi dari sebuah pernyataan, baik pernyataan majemuk maupun pernyataan berkuantor. Subjek tidak mampu menentukan negasi dari sebuah pernyataan majemuk dan pernyataan berkuantor secara benar. Negasi disamakan dengan operasi aljabar sebagai tanda negatif, sehingga dapat dioperasikan. Hal ini menunjukkan bahwa kemampuan subjek masih rendah.

c. Miskonsepsi pada konsep penentuan nilai kebenaran suatu pernyataan majemuk

Pada konsep ini mahasiswa FD mengalami miskonsepsi dalam menentukan nilai kebenaran suatu pernyataan majemuk. Subjek tidak memahami alur dalam menentukan nilai kebenaran suatu pernyataan majemuk. Subjek cenderung mencari nilai kebenaran dengan urutan dari depan. Hal ini menunjukkan bahwa kemampuan subjek masih rendah.

d. Miskonsepsi pada konsep tautologi, kontradiksi dan kontingensi

Pada konsep ini mahasiswa $F D$ mengalami miskonsepsi dalam membedakan antara tautologi, kontradiksi dan kontingensi. Pemahaman tentang ketiganya terbalik. Kontradiksi dipahami sebagai kontingensi. Hal ini menunjukkan rendahnya kemampuan subjek menyebabkan terjadinya miskonsepsi.

e. Miskonsepsi pada konsep invers, konvers, dan kontraposisi

Pada konsep ini mahasiswa $F D$ mengalami miskonsepsi dalam proses pencarian invers, konvers, dan kontraposisi. Sebenarnya subjek telah mampu membedakan antara ketiganya. Namun demikian, karena pemahaman yang salah dalam penentuan negasi, berakibat kesalahan pada penentuan invers, konvers, dan kontraposisi dari suatu pernyataan. Hal ini menunjukkan rendahnya kemampuan subjek, terutama dalam penentuan negasi menyebabkan miskonsepsi pada konsepkonsep selanjutnya termasuk halnya pada konsep invers, konvers, dan kontraposisi.

f. Miskonsepsi pada konsep penarikan kesimpulan (silogisme, modus ponens, dan modus tollens)

Pada konsep ini subjek masih belum mampu memahami secara benar tentang konsep silogisme, modus ponens, dan modus tollens. Hal ini berakibat pada 
kesalahan dalam menyelesaikan sebuah permasalahan terkait penentuan validitas suatu pernyataan. Hal ini juga mengindikasikan rendahnya kemampuan subjek $F D$ dalam memahami konsep silogisme, modus ponens, dan modus tollens.

g. Miskonsepsi pada konsep pembuktian langsung dan tidak langsung

Subjek tidak mampu membuktikan suatu pernyataan secara tidak langsung. Pembuktian yang dilakukan dengan cara melakukan permisalan. Hal ini tidak dibenarkan pada konsep logika. Permisalan tidak cukup untuk membuktikan valid tidaknya suatu pernyataan. Hal ini mengindikasikan masih lemahnya kemampuan mahasiswa dalam pembuktian secara tidak langsung.

Berbagai miskonsepsi mahasiswa $F D$ yang terjadi pada mata kuliah pengantar dasar matematika pokok bahasan logika sebagaimana diuraikan di atas memiliki penyebab yang berbeda-beda. Berikut akan diuraikan berbagai penyebab terjadinya miskonsepsi pada mahasiswa $F D$.

a. Intuisi yang salah

$$
\text { Mahasiswa mengungkapkan }
$$
gagasannya tentang suatu konsep secara spontan sebelum mempelajarinya terlebih dahulu. Ia cenderung mengikuti perasaannya saja. Miskonsepsi yang diakibatkan oleh intuisi yang salah seperti ini terjadi pada konsep terkait pernyataan dan bukan pernyataan.

b. Reasoning yang tidak lengkap
Mahasiswa mengalami penalaran yang salah, sehingga mengakibatkan reasoning yang tidak lengkap. Di sini terjadi Simplifikasi atau penyederhanaan dari makna yang sebenarnya lebih kompleks. Miskonsepsi yang diakibatkan oleh reasoning yang tidak lengkap seperti ini terjadi pada konsep terkait pernyataan dan bukan pernyataan.

c. Kemampuan mahasiswa

Rendahnya kemampuan mahasiswa mendominasi penyebab terjadinya miskonsepsi. Dengan kemampuan yang rendah, mengakibatkan jawaban yang salah. Miskonsepsi yang diakibatkan oleh rendahnyakemampuanmahasiswa seperti ini terjadi hampir pada seluruh konsep logika. Berdasarkan hasil wawancara diketahui bahwa memang kemampuan mahasiswa pada materi logika masih rendah. Ini tidak terlepas pendidikan sebelumnya yang bervariasi. Tidak sedikit dari mereka berasal dari sekolah menengah kejuruan yang notabene materi matematika tidak menjadi prioritas utama.

d. Prakonsepsi yang salah

Konsep awal yang tidak tepat dapat mengakibatkan miskonsepsi. Konsep awal yang dipahaminya sejak bangku sekolah membuatnya mengalami kesalahan. Karena sudah meyakini bahwa apa yang dilakukan benar, maka hal ini akan dilakukannya dengan penuh percaya diri meskipun sebenarnya apa yang dilakukannya tersebut salah. Prakonsepsi yang salah ini terjadi pada konsep pembuktian kalimat langsung dan tidak langsung. Mahasiswa meyakini 
bahwa pembuktian kalimat matematika dapat dilakukan dengan trial and error (mencoba-coba) memasukkan angka. Prakonsepsi yang salah juga tidak terlepas pendidikan sebelumnya yang bervariasi. Guru punya andil besar dalam terjadinya miskonsepsi. Hal ini diketahui berdasarkan hasil wawancara, bahwa pemahaman seperti ini diperolehnya sejak belajar di sekolah.

\section{Miskonsepsi mahasiswa Field independent}

Mahasiswa dengan gaya kognitif Field independent juga mengalami miskonsepsi pada konsep logika matematika. Dari sepuluh soal yang ada, dengan berbagai konsep masingmasing, menunjukkan bahwa mahasiswa FI mengalami miskonsepsi pada beberapa konsep, dengan berbagai bentuk miskonsepsi sebagai berikut.

a. Miskonsepsi pada konsep pernyataan atau bukan pernyataan

Pada konsep ini mahasiswa FI mengalami miskonsepsi dalam memberikan definisi kalimat terbuka. Definisi yang diberikan tidak sesuai dengan konsep logika. Demikian halnya dalam memberikan contoh. Beberapa mahasiswa FI benar dalam memberikan definisi, namun demikian salah dalam memberikan contoh.

b. Miskonsepsi pada konsep pernyataan majemuk dan pernyataan berkuantor beserta negasinya

Pada konsep ini mahasiswa FI mengalami miskonsepsi dalam menentukan negasi dari sebuah pernyataan berkuantor.
Subjek tidak mampu menentukan negasi dari sebuah pernyataan berkuantor secara benar. Negasi disamakan dengan operasi aljabar sebagai tanda negatif, sehingga dapat dioperasikan. Hal ini menunjukkan bahwa pemahaman subjek pada konsep negasi sebuah pernyataan berkuantor masih rendah.

c. Miskonsepsi pada konsep penentuan nilai kebenaran suatu pernyataan majemuk

Pada konsep ini beberapa mahasiswa FI mengalami miskonsepsi dalam menentukan nilai kebenaran suatu pernyataan majemuk. Subjek kurang memahami alur dalam menentukan nilai kebenaran suatu pernyataan majemuk. Subjek cenderung mencari nilai kebenaran dengan urutan dari depan. Hal ini menunjukkan pemahaman subjek dalam menentukan nilai kebenaran masih rendah.

d. Miskonsepsi pada konsep tautologi, kontradiksi dan kontingensi

Pada konsep ini mahasiswa FI mengalami miskonsepsi dalam membedakan antara tautologi, kontradiksi dan kontingensi. Kontradiksi dipahami sebagai sebuah kontingensi. Subjek mengakui bahwa dalam menjawab didasarkan pada sebuah intuisi, karena ia belum mempelajarinya terlebih dahulu.

e. Miskonsepsi pada konsep invers, konvers, dan kontraposisi

Pada konsep ini mahasiswa FI mengalami miskonsepsi dalam proses pencarian invers, konvers, dan kontraposisi. Sebenarnya subjek telah mampu membedakan antara ketiganya. Namun 
demikian, karena pemahaman yang salah dalam penentuan negasi, berakibat kesalahan pada penentuan invers, konvers, dan kontraposisi dari suatu pernyataan. Hal ini menunjukkan rendahnya kemampuan subjek, terutama dalam penentuan negasi menyebabkan miskonsepsi pada konsepkonsep selanjutnya termasuk halnya pada konsep invers, konvers, dan kontraposisi.

f. Miskonsepsi pada konsep penarikan kesimpulan (silogisme, modus ponens, dan modus tollens)

Pada konsep ini subjek masih belum mampu memahami secara benar tentang konsep silogisme, modus ponens, dan modus tollens. Hal ini berakibat pada kesalahan dalam menyelesaikan sebuah permasalahan terkait penentuan validitas suatu pernyataan. Hal ini juga mengindikasikan rendahnya kemampuan subjek FI dalam memahami konsep silogisme, modus ponens, dan modus tollens.

g. Miskonsepsi pada konsep pembuktian langsung dan tidak langsung

Subjek tidak mampu membuktikan suatu pernyataan secara tidak langsung. Pembuktian yang dilakukan dengan cara melakukan permisalan. Hal ini tidak dibenarkan pada konsep logika. Permisalan tidak cukup untuk membuktikan valid tidaknya suatu pernyataan. Hal ini mengindikasikan masih lemahnya kemampuan mahasiswa dalam pembuktian secara tidak langsung.

Berbagai miskonsepsi mahasiswa $F I$ yang terjadi pada mata kuliah pengantar dasar matematika pokok bahasan logika sebagaimana diuraikan di atas memiliki penyebab yang berbeda-beda. Berikut akan diuraikan berbagai penyebab terjadinya miskonsepsi pada mahasiswa FI.

a. Intuisi yang salah

Mahasiswa mengungkapkan gagasannya tentang suatu konsep secara spontan sebelum mempelajarinya terlebih dahulu. Ia cenderung mengikuti perasaannya saja. Sebagaimana mahasiswa Field dependent, mahasiswa Field independent juga mengalami miskonsepsi yang diakibatkan oleh intuisi yang salah.

b. Reasoning yang tidak lengkap Sebagaimana mahasiswa Field dependent, mahasiswa Field independent juga mengalami miskonsepsi yang diakibatkan oleh reasoning yang tidak lengkap. Penalaran yang salah dapat mengakibatkan reasoning yang tidak lengkap. Di sini terjadi Simplifikasi atau penyederhanaan dari makna yang sebenarnya lebih kompleks.

c. Prakonsepsi yang salah

Prakonsepsi mahasiswa Field independent yang salah dapat mengakibatkan miskonsepsi. Konsep awal yang dipahaminya sejak bangku sekolah membuatnya mengalami kesalahan yang berkelanjutan. Karena sudah meyakini bahwa apa yang dilakukan benar, maka hal ini akan dilakukannya dengan penuh percaya diri meskipun sebenarnya apa yang dilakukannya tersebut salah. Prakonsepsi yang salah ini terjadi pada konsep pembuktian kalimat langsung dan tidak 
langsung. Mahasiswa meyakini bahwa pembuktian kalimat matematika dapat dilakukan dengan trial and error (mencobacoba) memasukkan angka. Prakonsepsi yang salah juga tidak terlepas pendidikan sebelumnya yang bervariasi. Guru dan lingkungan belajar pada saat SMA, punya andil besar terhadap terjadinya miskonsepsi. Hal ini diketahui berdasarkan hasil wawancara, bahwa pemahaman seperti ini diperolehnya sejak belajar di sekolah.

Berdasarkan hasil pembahasan tersebut di atas, maka dapat dikatakan bahwa mahasiswa dengan gaya kognitif Field dependent mengalami miskonsepsi pada materi logika. Penyebab miskonsepsi pada mahasiswa Field dependent didominasi oleh kemampuan yang dimiliki mahasiswa. Meskipun demikian, ada miskonsepsi pada beberapa konsep yang diakibatkan oleh intuisi yang salah, reasoning yang tidak lengkap, dan juga prakonsepsi yang tidak benar. Sementara itu, miskonsepsi yang terjadi pada mahasiswa Field independent lebih didominasi oleh intuisi yang salah dan reasoning yang tidak lengkap. Selain itu juga terdapat miskonsepsi yang diakibatkan oleh prakonsepsi yang salah. Namun secara kuantitas maupun proporsi, miskonsepsi mahasiswa Field dependent lebih tinggi dibandingkan dengan miskonsepsi yang dialami mahasiswa Field independent. Hal tersebut sejalan dengan penelitian yang dilakukan oleh Alessandro Antonietti dan Maria Alfonsa Gioletta (1995) yang berjudul "Individual Differences in Analogical Problem Solving" yang mengatakan bahwa siswa dengan gaya kognitif Field independent lebih mampu menyelesaikan masalah dibandingkan dengan siswa yang memiliki gaya kognitif Field dependent.

\section{SIMPULAN}

Berdasarkan analisis dan pembahasan yang telah dilakukan, diperoleh beberapa kesimpulan sebagai berikut:

1. Mahasiswa $F D$ mengalami miskonsepsi di semua konsep logika. Miskonsepsi tertinggi mahasiswa $F D$ terjadi pada konsep invers, konvers, dan kontraposisi. Berdasarkan tes diagnostik miskonsepsi diketahui bahwa sebesar $38 \%$ mahasiswa $F D$ mengalami miskonsepsi pada konsep tersebut.

2. Mahasiswa FI mengalami miskonsepsi pada beberapa konsep logika. Miskonsepsi tertinggi mahasiswa FI terjadi pada konsep negasi pernyataan majemuk dan pernyataan berkuantor. Berdasarkan tes diagnostik miskonsepsi diketahui bahwa sebesar $32 \%$ mahasiswa FI mengalami miskonsepsi pada konsep tersebut.

3. Miskonsepsi pada mahasiswa $F D$ lebih banyak diakibatkan oleh prakonsepsi yang salah dan rendahnya kemampuan mahasiswa. Di samping itu juga disebabkan oleh intuisi yang salah, reasoning yang tidak lengkap, dan Simplifikasi.

4. Miskonsepsi pada mahasiswa FI lebih banyak diakibatkan oleh Simplifikasi dan intuisi yang salah. Di samping itu juga disebabkan oleh reasoning yang tidak lengkap.

\section{DAFTAR PUSTAKA}

Altun, A., dan Cakan, M. 2006. "Undergraduate Students' Academic Achievement, 
Field Dependent/Independent

Cognitive Style and Attitude toward Computers". Educational Technology \& Society. 9(1). 289-297.

Atasoy, B., Guyer, T., dan Somyurek, S. 2008.

"The Effect of Individual Differences on Learner's Navigation in a Courseware". The Turkish Online Journal of Educational Technology. 7(2). 32-40.

Bostic, J. Q. 1988. Cognitive Styles: Their Consolidation and Relationship, Beyond Cognitive Developmental Level and Critical Thinking Ability, to Understanding Science. Disertasi. Texas: Texas Tech University.

Desmita. 2009. Psikologi Perkembangan Peserta Didik. Bandung: PT Remaja Rosdakarya.

Djam'an Satori dan Aan Komariah. 2010. Metodologi Penelitian Kualitatif. Bandung: Alfabeta.

Dyer, J. E. dan Osborne, E. W. 1996. "Effects of Teaching Approach on Problem Solving Ability of Agricultural Education Students With Varying Learning Styles". Journal of Agricultural Education. 37(4). 38-45.

Den Berg, E. V. 1991. Miskonsepsi Fisika dan Remidiasi. Salatiga: UKSW.

Fyle, C. O. 2009.The Effects of Field Dependent/Independent Style Awareness on Learning Strategies and Outcomes in an Instructional Hypermedia Module. Disertasi. Florida: Florida State University.
Guisande, M. A., Paramo, M. F., Tinajero, T., Almeida, L.S. 2007. "Field dependentIndependent (FDI) Cognitive Style: An Analysis of Attentional Functioning". Psicothema. 19 (004). 572-577.

Hasan, S., Bagayko, D., dan Kelley, E. L. 1999. "Misconception and the Certainty of Response Index (CRI)". Phys. Education. 34(5). 294-299.

Hayes, J. Dan Allinson, C. W. 1998. Cognitive Style and the Theory and Practice of Individual and Collective Learning in Organizations. Human Relations. 51(7). 947-871.

Ibnu Suhadi. 1989. Kesalahan Atas Pemahaman Konsep-konsep IPA dalam Konteks Pendidikan di Indonesia. Malang: IKIP.

Lexy J. Moloeng. 2006. Metodologi Penelitian Kualitatif. Bandung: Remaja Rosdakarya. Lin, J. Dan Chen. H. 2008. Discovering learning in different cognitive style of learners. Taiwan: Departement of Information Management Chaoyang University of Technology.

Marsudi. 2010. Logika dan Teori Himpunan. Malang: UB Press.

Moh. Amien. 1987. Mengajarkan Ilmu Pengetahuan Alam dengan Metode "Discovery" dan "Inkuary”. Jakarta: Dirjen Dikti P²LTK.

Muhammad Haffan. 2001. Identifikasi Miskonsepsi Belajar Matematika Beserta Remediasinya. Tesis pada PPs-UPI: Tidak diterbitkan.

Mulyono. 2002. Penerapan Pembelajaran Model Pencapaian Konsep untuk 
Meningkatkan Hasil Belajar

Matematika Siswa SMU. Tesis pada

PPs-UPI: Tidak diterbitkan.

Nana Syaodih Sukmadinata. 2010. Metode Penelitian Pendidikan. Bandung:

Remaja Rosdakarya.

Nur Aedi. 2010. Pengolahan dan Analisis Data

Hasil Penelitian. Bahan Belajar

Mandiri UPI: Tidak diterbitkan.

O’Brien, T. P., Butler, S. M., dan Bernold, L. E. 2001. "Group Embedded Figures Test and Academic Achievement in

Engineering Education”. Int. J. Engng Ed. 17(1). 89-92.

Eunjoo Oh dan Lim, D. 2005. "Cross

$\underline{\text { Relationships between Cognitive Styles }}$ and Learner Variables in Online

Learning Environment". Journal of Interactive Online Learning. 4(1). 5366.

Parkinson, A.,dan Redmon, J. A. 2001. The Impact of Cognitive Styles and Educational Computer Environments on Learning Performance. Dublin: Dept of Computer Science, Trinity College.

Paul Suparno. 2005. Miskonsepsi dan Perubahan Konsep Pendidikan FIsika. Yogyakarta: PT Gramedia Widiasarana Indonesia.

Ratna Wilis Dahar. 1996. Teori-teori Belajar. Jakarta: Erlangga.

S. Nasution. 2010. Berbagai Pendekatan dalam

Proses Belajar \& Mengajar. Bandung:

Bumi Aksara.

Soedjadi. 1995. Miskonsepsi Dalam Pengajaran Matematika (Pokok-pokok
Tinjauan Dikaitkan dengan

Konstruktivisme). Surabaya: Media

Pendidikan dan Ilmu Pengetahuan IKIP Surabaya.

Srivastava, P. 1997. Cognitive Style in Educational Perspective. New Delhi: Anmol Publications Pvt Ltd.

Sugiyono. 2011. Metode Penelitian Kuantitatif, Kualitatif dan R\&B. Bandung: Alfabeta.

Surya Dharma. 2008. Pengolahan dan Analisis Data Penelitian. Jakarta: Ditjen PMPTK, Depdiknas.

Syaifuddin Azwar. 2007. Metode Penelitian. Yogyakarta: Pustaka Pelajar.

W. Sunarno. 1988. Model Remediasi Miskonsepsi Dinamika Menggunakan Animasi Simulasi Dengan Komputer. Disertasi pada PPs-UPI: Tidak Diterbitkan.

Wahidmuri. 2008. Cara Mudah Menulis Proposal dan Laporan Penelitian Lapangan.Malang: UM Press.

Winny Liliawati dan Taufik Ramlan. 2008. Identifikasi Miskonsepsi Materi IPBA di SMA dengan Menggunakan CRI (Certainty of Response Index) dalam Upaya Perbaikan dan Pengembangan Materi IPBA pada KTSP. Laporan Penelitian Pembinaan UPI. Bandung: Lembaga Penelitian UPI. 